\title{
Corruption And Discourse Renewal in the Ministry of Agriculture: A Study of Crisis Communications
}

\author{
Astri Wibawanti Putri \\ Communication Studies Program \\ Sebelas Maret University \\ Surakarta, Indonesia \\ astriputri10@gmail.com
}

\author{
Andre N Rahmanto \\ Communication Studies Program \\ Sebelas Maret University \\ Surakarta, Indonesia
}

\begin{abstract}
The organizational ability to learn from the crisis and explore the opportunities that still exist is a positive step that can improve the credibility of the organization in the eyes of stakeholders and the community. This study attempts to use a new approach in assessing crisis communications conducted by the Ministry of Agriculture. During this time, research on communication crisis in Indonesia majority use theory of Image Restoration or Situational Crisis Communication Theory. Therefore, researchers try to use the Discourse of Renewal from Seeger, Ulmer and Sellnow to analyze communication messages issued by the Ministry of Agriculture related to corruption cases. The data used comes from the news in online media during the leadership of the Minister of Agriculture Andi Amran Sulaiman. The messages are examined using the theoretical framework of the renewal discourse that emphasizes provisional communication, prospective, optimistic communication and leader-based communication. This article is part of the ongoing research process.
\end{abstract}

Keywords - crisis communication; corruption; discourse of renewal theory

\section{INTRODUCTION}

Corruption is still one of the problems faced by the Indonesian. Corruption cases that drag public officials threaten the success of government programs and reduce public confidence to the government. In the first half of 2017, Indonesian Corruption Watch (ICW) noted that there are 226 cases of corruption. The number of suspects during the period was 587 people and and cost the state as much as Rp 1.83 trillion, with bribes of Rp 118.1 billion [1].

ICW also considers that the Ministry of Agriculture is very vulnerable to corruption cases. This was said by Emerson Yunto from ICW on the discussion titled "Homework of the Ministry of Agriculture" in Cikini, Central Jakarta, Sunday (2/11/2014). This is because the Ministry of Agriculture (MoA) is one of the Ministry with the largest budget. Moreover, there was some corruption cases in the past, including alleged bribery of beef imports involving PKS President Luthfi Hasan Ishak and a number of private parties, alleged project of seeds procurement by PT Sang Hyang Seri (SHS), the alleged corruption project of light trap from Director General of Food Crops, alleged corruption of coffe seeds project procurement that cost to Rp 12 billion, and alleged corruption of liquid decomposer project and liquid fertilizer valued at Rp 81 billion. Because of that,
ICW interpreted that the Ministry is prone to become a land of corruption [2]. Beside ICW, Abraham Samad, former Chairman of KPK 2011-2015 also said that the food security sector is prone to corruption because of a very significant turnover of money. Corruption in imported meat and imported sugar that ever dismantled by the KPK is one example of how this food security sector is prone to corruption [3]. Responding to this, the Special Staff for Ministerial Policy from the Ministry of Agriculture, Sukriansyah S Latief, revealed that in the last three years, Ministry of Agriculture not only solve the food problem, but also do the mental reform of Agriculture human resources (HR) and discipline apparatus. There have been many breakthroughs conducted by the Minister of Agriculture to foster the apparatus, provide a deterrent effect, and clean-up from corruption, collusion and nepotism (KKN) [4].

Furthermore, Abraham Samad also warned that if the potential for corruption is not handled properly, food selfsufficiency may be hampered by corruption which in turn may disrupt the tranquility of villagers, considering that 70 percent of Indonesians live in rural areas [3]. Corruption has become a crisis for the Ministry of Agriculture, therefore, appropriate crisis communication is needed in order to mitigate the adverse effects of the crisis. Kathleen Fearn-Banks said that crisis communication is a process of dialogue between companies and the public that aims to deal with crisis that happen in the company [5]. More specifically, Seeger and Sellnow say that crisis communication is an ongoing process for creating shared meaning among groups, communities, individuals and institutions, in the ecological context of a crisis, for the purpose of preparing and reducing, limiting and responding to threats and dangers [6, p. 13]. The basic of crisis communication is to respond quickly once the crisis occurs, with open and honest messages to the stakeholders either affected directly or not directly [7].

There are four major categories in responding to the crisis, that is to deny, diminish, rebuild, and reinforce [8]. A denial strategy is better used to address rumors or issues. Crisis caused by accidents or past history is usually handled using a diminish strategy. Strategies to rebuild are usually used to anticipate a crisis. The strategies include compensation, apology, corrective action and benefits. The crisis communication strategies are divided into various theories, for example Apologia Theory rooted in the genre of rhetoric and refers to the efforts of self-defense [9, p. 176]. Image Restoration Theory presents strategies to restore the image in 
order to overcome the crisis. Only, the focus of the study is on the selection of communication messages to improve the image [9, p. 227].There is another theory called Situational Crisis Communication Theory that developed by Timothy W Coombs. This theory discusses how a person or an agency is behaving towards the crisis. This theory explained about the organizational response that is determined by the attribution of society to the responsibility of the organization in handling the crisis [10].

The new theory of crisis communication is a Discourse of Renewal theory that differs from other forms of crisis communication. The goal is to restore image by focusing on strong value positions, responsibilities to stakeholders, and growth as a result of the crisis [11]. Discourse of Renewal Theory no longer sees crisis as something negative but views crisis as an opportunity to move in a better direction, beyond its previous limitations. The theoretical framework Discourse of Renewal uses an emphasis on its organizational change through provisional communication, prospective, optimistic and leader-based communications [12]. Provisional messages are spontaneous and unplanned messages. The messages are not planned professionally but emerging from natural improvisation. Prospective messages focus on delivering the vision of the future and not as an outpouring of error or regret. The optimistic message embraces the potential opportunities that are now available as a result of the crisis, and leader-based communication includes messages based on the core values and beliefs of organizational leaders [13].

\section{Methodology}

This article uses qualitative methods with case study design in order to gain an in-depth understanding of the use of the Discourse of Renewal theory as one of crisis communication. The four characteristics of the Discourse of Renewal are used as an analytical structure to find out the renewal discourse in communications conducted by the Ministry of Agriculture. The data used in this study is taken online in the form of news in the mass media and also releases issued by the Ministry of Agriculture. The news period is during the reign of Agriculture Minister Andi Amran Sulaiman from 2014-2018.

The data retrieval system uses purposive sampling, by selecting news which has a statement or discourse of prevention and eradication of corruption. The results are then grouped according to the characteristics of the Discourse of Renewal and will be use as evidence of the theory usage in its crisis communication strategy. These four characteristics will become a framework in coding data. The coding framework is taken from Karen Kay Barone's dissertation entitled "Analyzing Discourse of Renewal Post-Crisis Organizational Resilience Among Nonprofit Organizations" [12].

The researcher use google.com to collect the data. There are 16.500.000 search results in google with keyword "Ministry of Agriculture", 4,060,000 search results with keyword "Corruption in The Ministry of Agriculture" and 66,500 search results with keyword "Statement Minister of Agriculture About Corruption in The Ministry of Agriculture”. From these results are then selected in accordance with the topic and discussion of research. After that, all the statement of the minister of agriculture or the other officials will be put on a table and will be analyze using coding framework from Karen Kay Barone.

\section{CORRUPtion In The Ministry OF AgRiculture}

The biggest case that got more attention from the public and makes the image of the Ministry of Agriculture deteriorate is a corruption case of the beef import quota in 2013. To clarify the plot of crisis communication conducted, researchers will use the five stages of crisis from the book entitled Crisis Public Relation written by Firsan Nova [14].

First called pre-crisis, the situation before the crisis. At this time, organizations should prepare themselves by making SOP of crisis handling or creating a clear workflow in the event of a crisis. But like most government agencies at that time, the Ministry of Agriculture did not have a detail SOP for crisis management.

The second stage is warning. In this phase, many issues or rumors arose in the community. For example, in the corruption of beef import quota at MoA, there is an issues that the demand for import quotas only available for large companies. This issues has emerged since 2011 [15]. This case reemerged and became the public spotlight for allegedly involving the president of Partai Keadilan Sejahtera (PKS) at that time, Luthfi Hasan Ishaaq [16] and there is allegedly the involvement of the Minister of Agriculture in the determination of beef import quota.

There are so many incoming complaints about beef import quota to the KPK during the period of 2005 - 2012. That is the reason why KPK conduct Policy Analysis On Beef Commodity Strategic Trade. This study was conducted to investigate allegations of corruption related to beef commodities. The study resulted in several findings: (1) The trading policy does not reflect the alignment of 6.2 million smallholders, small and medium-scale farmers, (2) The marketing policy does not lead to the development of the beef industry in production centers, (3) There is a weakness in import policies and procedures due to the domination of rent-seeking practices and cartels [17].

The third stage is the crisis stage (acute), that is when the crisis began to form and known by the media and society. At this stage, inevitably the company or institution must prepare. On January 31, 2013 evening, the office of the Director General of Livestock and Animal Health Services was suddenly sealed by the KPK for the investigation process. This makes the Ministry of Agriculture forced to serve the attention of the public and the media who want to know the case. This crisis happened in 2013, a year before the president election. So many people assume that the case is loaded with political content. Therefore the former Minister of Agriculture was very cautious and only gave little clarification. President Susilo Bambang Yudhoyono finally summoning the Minister of Agriculture Suswono, to discuss the legal issues of the case and national food security [18]. The Supreme Audit Agency (BPK) concluded that beef imports in 2010-2011 exceeded the predetermined plans. The certainty is obtained because the import data in the Agricultural Quarantine Agency and the 
Directorate General of Customs and Excise are much different [19]. This case makes the Ministry of Agriculture and the Ministry of Trade claim each other that what they did was right, even throwing faults at each other. Vice Minister of Trade Bayu Krisnamurthi stated and even able to prove to the KPK that the quota allocation table of imports per company has been prepared first by the Ministry of Agriculture. Ministry of Trade can not refuse because the authority on the recommendation of approval is in MoA [16].

The turn of Minister in 2014 becomes a kind of anti-climax in the crisis due to corruption. The new minister has a huge homework to restore the image of the Ministry of Agriculture that is deteriorating due to corruption. This phase is included in the clean-up stage, the fourth stage of the crisis. At this stage, various ways must be taken to improve the reputation and ensure that similar crises will not recur. The bribery case of beef imports is a valuable lesson for the Ministry of Agriculture. Firsan Nova [14, p. 78] in his book mentions several factors causing the crisis and one of them is the crisis due to public perception. Bad public perception could make an organization experiencing another crisis because of the previous crisis is not resolved well, so its potential losses become multiplied.

After the corruption case of beef import quota that eventually dragged one of the political party's top officials behind bars, the Ministry of Agriculture still suffered several corruption cases that dragged its public officials. Therefore, researchers feel interest to analyze the crisis communication conducted by the Ministry of Agriculture. This corruption cases need a special treatment because if its not properly handled, it could potentially damage the positive image of ministries and agencies, not only in the agricultural sector but even all government agencies. Being defensive is no longer a proper crisis communication. People need strong evidence and commitment from leaders to get together seriously against corruption.

\section{Discourse of Renewal in The MoA}

Repeated corruption cases that involving officials at the Ministry of Agriculture make people think that the Ministry is very vulnerable to corruption. On Nopember 2014, ICW has warned the new Minister of Agriculture about huge homework in eradication of corruption [20]. Denying crisis, finding scapegoats, or even apologizing to the public will not alter the negative perceptions that already established. People want concrete steps taken by the Ministry to eradicate corruption.

Researcher have collected 53 news topics containing messages of prevention and eradication of corruption during the period of October 2014 to April 2018. There are statements from the Minister of Agriculture and the other officials such as Head of Public Relations and Public Information Bureau, Director of Vegetables and Medicinal Plants Directorate General Horticulture, Inspector General of MoA, Head of Agriculture Quarantine Agency, Head of Data Center and Information, and Director General of Infrastructure and Agricultural Facility. Mostly, the leaders will remind the firm commitment of Minister of Agriculture to crack down on corrupt perpetrators. Some stakeholders also provide statements and opinions regarding actions that have been done by MoA to combat corruption. Some of these stakeholders are members of Commission IV of DPR-RI, ICW and KPK.

\section{A. Provisional Messages}

According to Indonesian Language Dictionary (KBBI), provisional means temporary. In the Discourse of Renewal, provisional messages are messages that are spontaneous and unplanned. The messages are not planned professionally but emerging from natural improvisation. For certain events, the crisis creates a strong emotional response to people committed to resurrection. This action usually focuses on what is best for society as a whole and not a strategic response that only benefits some people [13].

According to the news in the media, the discourse of prevention and eradication of corruption committed by the Minister of Agriculture or the other officials in MoA spread in so many event, not always related to corruption. In various event, the Minister or his officials often insert anti-corruption messages and also a firm statement to immediately dismiss persons who are found guilty. Harvesting activities or field visits from the Ministry of Agriculture are widely used as a means of education that MoA is seriously to eradicate corruption. Complaints from farmers and ranchers on illegal charge or corruption are addressed firmly by the Minister of Agriculture. For example, when Minister of Agriculture attended a meeting to improve the rice industry, the Minister responded to a complaint from one of the farmer from Sukabumi who reported that assistance from MoA had to be redeemed with some money. Minister of Agriculture persuaded the farmer to mention the person name who did the illegal charge. When the farmer finally mentioned the name of the person by whispering, the Minister said that he would crack down on the person [21].

Minister of Agriculture is also not afraid to give a statement related to corruption cases that ensnare the former Director General. When confirmed in the case of alleged bribery that ensnare Patrialis Akbar, again the Minister of Agriculture threatened "If anyone involved in the Ministry, I fired!". He was furious because the act of one or two people, has made his institution's image worse [22].

Some of the anti-corruption messages that are often delivered by the Minister of Agriculture are adopted by other leaders. For example, Head of Data Center and Information, Inspector General, or Head of The Agricultural Quarantine Agency on several occasions recalled the steps that have been done by the Minister of Agriculture to eradicate corruption, even the attitude of the Minister who rejects nepotism.

\section{B. Prospective Messages}

Prospective messages focus on delivering the vision of the future and not as an outpouring of error or regret. Many crisis communications are done to minimize losses or protect the image of the organization, either by searching for denying, searching for scapegoats, and others. Discourse of Renewal focuses more on "looking forward" communication. In prospective communication, organizations focus on how organizations can move forward. Post-crisis communications 
focus more on how to rebuild, rather than address the problem or who is at fault.

Many breakthroughs have been done by the Minister of Agriculture related to the prevention and eradication of corruption. In Karen Kay Barone's Coding Framework [12], prospective messages are a vision-oriented message, including more future-focused messages and moving organizations forward. In the prevention and eradication of corruption, Minister of Agriculture has conducted some very prospective actions, related to agricultural governance. Amran undertook a mental revolution on MoA employees through: (1) To oversee the program and budget,to comply with applicable regulation, Minister of Agriculture placing Corruption Eradication Commission (KPK) Officer, Republic Indonesian Police Officer, and Attorney General's Officer at the MoA.; (2)Together with the Minister of Trade, Chief of Police, Head of The Logistics Agency (Kabulog), Commission for the Supervision of Business Competition (KPPU) formed Food Task Force; (3)The job auctions are professionally and transparently; (4) Educate discipline work full-time per day and plunge directly in the field; (5) Designing and working on the program in a focused and measurable way; (6) Program monitoring daily or weekly; and (7) Applies strict reward and punishment patterns and various other policies.

The Minister of Agriculture also made a policy of agricultural human resource management with daily monitoring and evaluation, and formed a Clean Sweep Team. The result, of more than 40 cases of illegal fertilizer and fertilizer circulation has been processed by law [23]. These major successes mostly will be reiterated by other officials, for example by the Head of the Agricultural Quarantine Agency when awarding the Anti-Bribery Management Certificate to the Makassar Quarantine Center [24].

\section{Optimistic Messages}

This third characteristic focuses on the organizational ability to reconstitute itself by taking advantage of the opportunities covered by the crisis. An upbeat message embraces the potential opportunities that are now available as a result of the crisis [13]. The stakeholders will be inspired by the behavior of the model if there is a positive outcome. The strength, vision and reputation of a formal leader is a necessary condition for renewal. Leaders play an important role in renewal because they embody the company and its value.

These optimistic messages appear more frequently in formal occasions attended by the Minister of Agriculture or other leaders, for example at the time of MoA's new employees preparation or at the commemoration of Anti Corruption Day. But if it compared with the achievement of the performance, the Minister did not much indulgence optimism. The most important is a proactive attitude and uphold the values of honesty and anti-corruption. One of his statements when giving a speech to the new employees is "Move together in order to change the face of agriculture, the face of Indonesia, can even thrill the world". When there's another employees arrested for the corruption of the Farmers Aid Fund, the Minister of Agriculture pleased and even thanked to the performance of the Attorney General's Office which was deemed to have helped MoA to rid of corruption.

\section{Message-Based Values and Leaders Ethics}

Post-crisis responses that focus on renewal often originated from the values and virtues of organizational leaders. Leaderbased communication includes messages that based on the core values and beliefs of organizational leaders [13]. The most successful organizations generate a renewal response to the crisis, not only communicating the responses to update or fix problems, but have followed up with meaningful actions and observable changes [13]. Leader-based messaging is an impression created by the value that appear from his or her own personal, as well as the values and ethics that always appear and over time become the hallmark of the organization's attitude.

Minister of Agriculture, Andi Amran Sulaiman is known as someone who is intelligent, innovative, honest and a problem solver. He is also known to have the ability in the field of agriculture, quite capable and have advanced thinking power. Strict statements are often made about officials who allegedly involved in corruption cases. He did not hesitate to dismiss his employees if convicted. Its firmness and honesty is one of the weapons to regain public confidence in the government. However, the renewal delivered will not succeed unless accompanied by a strong commitment from the ranks of the leadership. Statements from members of Commission IV of the House of Representatives Firman Subagyo confirmed that Minister Amran were brave figures against the food mafia. In every occasion, Minister of Agriculture always emphasizes the value of honesty, good work, loyal to the Ministry, integrity and anti-corruption, especially to the new employees of MoA.

\section{CONCLUSION}

From the news that appears in the media, clearly seen the firmly commitment from Minister of Agriculture and also the prospective attitude to the prevention and eradication of corruption in the scope of Ministry. Although the optimistic impression is not much highlighted by the Minister of Agriculture itself, but the optimistic impression is seen from the response of stakeholders to the majority of actions and policies that have been taken by MoA. The main values brought by Andi Amran Sulaiman personally as Minister of Agriculture stand out and become the driving force of change inside MoA. His firm, honest and strong anti-corruption attitude makes MoA stakeholders respect and trust in their performance.

This study is only a small part of the thesis research related Discourse of Renewal in the scope of the Ministry of Agriculture. This news collection gives us some insight that crisis communications should be made every chance. Changing perceptions is not as easy as opening the palms so it takes consistent and continuous action with positive values that are firmly held. Gradually with the positive evidence that continues to be collected and communicated, then the positive change of the image is worth to waiting for. 


\section{REFERENCES}

[1] I. Hariyanto, "ICW: Dalam 6 Bulan, 226 Kasus Korupsi Rugikan Negara Rp 1,83 T [ICW: In 6 Months, 226 Corruption Cases Results in State Loss of Rp1.83 trillion]," https://news.detik.com, August 30, 2017. [Online]. Available: https://news.detik.com/berita/d-3621894/icwdalam-6-bulan-226-kasus-korupsi-rugikan-negara-rp-183-t [Accessed June 5, 2018].

[2] N. Suartika, "Kementerian Pertanian Rawan Jadi Ladang Korupsi [Ministry of Agriculture Prone to be a Corruption Field]," https://news.okezone.com, November 2, 2014. [Online]. Available: https://news.okezone.com/read/2014/11/02/337/1060031/kementerianpertanian-rawan-jadi-ladang-korupsi [Accessed June 7, 2018].

[3] Sunariyah, "Ketahanan Pangan Rawan Korupsi, Abraham Samad Minta KPK Lakukan Ini [Food Security Prone to Corruption, Abraham Samad asks KPK to do this]," March 31, 2018. [Online]. Available: https://www.liputan6.com/news/read/3418065/ketahanan-pangan-rawankorupsi-abraham-samad-minta-kpk-lakukan-ini [Accessed June 11, 2018].

[4] U. Mukhtar, "Sektor Pangan Dituding Rawan Korupsi, Ini Tanggapan Kementan [Food Sectors Blamed as Prone to Corruption, This is Agricultural Ministry’s Response]," April 1, 2018. [Online]. Available: https://www.republika.co.id/berita/nasional/hukum/18/04/01/p6ht8f382sektor-pangan-dituding-rawan-korupsi-ini-tanggapan-kementan [Accessed June 11, 2018].

[5] K. Fearn-Banks, Crisis Communications; A Casebook Approach (4th ed.), New York: Routledge, 2011.

[6] T. L. S. a. M. W. Seeger, Theorizing Crisis Communication, UK: WileyBlackwell, 2013.

[7] N. M. Prastya, "Media Sosial dan Peran Manajerial Public Relations (Studi Kasus Terhadap Peran Bidang Komunikasi Korporat PT PLN Persero Dalam Penyusunan Kebijakan Terkait Etika Penggunaan Media Social di Lingkungan Perusahaan) [Social Media and Public Relations Managerial Role (Case Study of Corporate Communication Sectore of PT. PLN in Policy Making related to Social Media's Usage Ethics on the Company's Internal Affairs],” Masters' Thesis, Facult. Soc. Sci. and Polit., Yogyakarta, 2013.

[8] B. F. L. a. A. B. Levenshus, "Crisis Public Relations for Government Communicators," in The Practice of Government Public Relations, CRC Press, 2012, pp. 101-124.

[9] R. Kriyantono, Teori Public Relations Perspektif Barat dan Loka [Public Relations Theory, Western and Local Perspective], Jakarta: Kencana, 2014.

[10] W. T. C. a. S. J. Holladay, "The Negative Communication Dynamic: Exploring The Impact of Stakeholder Affect on Behavioral Intentions," J. of Commun. Manage., vol. 11, pp. 300-12, 2007.

[11] R. R. U. a. T. L. Sellnow, "Crisis Management and The Discourse of Renewal: Understanding The Potential for Positive Outcomes of Crisis," Pub. Rel. Rev., vol. 28, pp. 361-365, 2002.

[12] K. K. Barone, Analyzing Discourse of Renewal in Post-Crisis Organizational Resiliency Among Nonprofit Organizations. 2014.
[13] M. W. S. a. T. L. S. R. Ulmer, "Post-Crisis Communication and Renewal: Parameters of Post-Crisis Discourse," Pub. Rel. Rev., p. 130 134, 2007.

[14] F. Nova, Crisis Public Relations, Strategi PR Menghadapi Krisis, Mengelola Isu, Membangun Citra, dan Reputasi Perusahaan [Crisis Public Relations: PR Strategy Facing Crisis, Mananging Issues, Building Images, and Company’s Reputation]. Jakarta: Rajawali Pers, 2011.

[15] "Skandal Daging Berjanggut, Laporan Tempo 2011 [Bearded Mea Scandal, Tempo’s Report 2011]," Tempo.co, January 31, 2013. [Online]. Available: https://m.tempo.co/read/news/2013/01/31/063458099/skandal-dagingberjanggut-laporan-tempo-2011 [Accessed June 1, 2018].

[16] "Celah Kebijakan Impor Daging Sapi [Loophole on Meat Imports Policy]," Kompas.com., February 5, 2013. [Online]. Available: http://ekonomi.kompas.com/read/2013/02/05/05155267/Celah.Kebijaka n.Impor.Daging.Sapi [Accessed June 1, 2018].

[17] Direktorat Penelitian dan Pengembangan KPK, "Kajian Kebijakan TataNiaga [Commerce Policy Review]," KPK, Jakarta, Feb. 20, 2013.

[18] "Dipanggil SBY, Suswono Jelaskan kasus Impor Daging [Called by SBY, Suswono Explains the Meat Imports Scandals]," Tempo.co. February 13, 2013. [Online]. Available: https://nasional.tempo.co/read/461004/dipanggil-sby-suswono-jelaskankasus-impor-daging [Accessed June 1, 2018].

[19] "BPK Pastikan Impor Daging Lebihi Izin [BPK Assures Meat Imports Exceeds Permit]," Kompas.com, February 15, 2013. [Online]. Available: https://lifestyle.kompas.com/read/2013/02/15/02550737/bpk.pastikan.im por.daging.lebihi.izin [Accessed June 1, 2018].

[20] S. Riyandi, "Mentan Baru Punya Beban Berantas Korupsi Pertanian [New Agriculture Minister Got New Job to Eradicate Agriculture Coruption]," November 2, 2014. [Online]. Available: https://www.merdeka.com/uang/mentan-baru-punya-beban-berantaskorupsi-pertanian.html [Accessed June 1, 2018].

[21] E. A. Retaduari, "Gaya Kocak Mentan Amran Saat Dengarkan Curhatan Petani [Hilarious Style of Agriculture Minister on Farmers Hearing Session]," August 26, 2015. [Online]. Available: https://news.detik.com/berita/d-3002244/gaya-kocak-mentan-amransaat-dengarkan-curhat-petani/ [Accessed June 1, 2018].

[22] Tim Viva, "Ancaman Menteri Pertanian Untuk Pegawai Yang Korupsi [Agriculture Minister's Threat for Corruptive Employees]," February 24 2017. [Online]. Available: https://www.viva.co.id/berita/bisnis/887305ancaman-menteri-pertanian-untuk-pegawai-yang-korupsi [Accessed May 25, 2018].

[23] "Ini Gebrakan dan Kinerja Menteri Pertanian [This is the Breakthorugh and Performance of Agriculture Minister]," nusakini.com, August 2, 2016. [Online]. Available: http://www.nusakini.com/news/ini-gebrakandan-kinerja-menteri-pertanian [Accessed May 25, 2018]

[24] M Studio, "Pertama di Indonesia, Sertifikat Manajemen Anti Penyuapan Diberikan kepada Karantina Makassar [First in Indonesia, Anti-Bribing Management Certificate given to Makassar Quarantine Office]," December 14, 2017. [Online]. Available: http://ekonomi.metrotvnews.com/mikro/wkBnjzlk-pertama-diindonesia-sertifikat-manajemen-anti-penyuapan-diberikan-kepadakarantina-makassar [Accessed May 25, 2018]. 